\title{
Secreted Phosphoprotein 1 Promoter Genetic Variants Are Associated with the Response to Pegylated Interferon $\alpha$ Plus Ribavirin Combination Therapy in Egyptian Patients with Chronic Hepatitis C Virus Infection
}

\author{
Fahmy T. Ali*, Mohamed A. M. Ali*, Mayada M. A. Elgizawy ${ }^{\dagger}$, and Ahmed M. Elsawy ${ }^{\ddagger}$ \\ ${ }^{*}$ Department of Biochemistry, Faculty of Science, Ain Shams University, ${ }^{\dagger}$ Medical Research Laboratories and ${ }^{\ddagger}$ Internal Medicine Hospital, \\ Armed Forces Medical Complex, Kobry Elqobba, Cairo, Egypt
}

\begin{abstract}
Background/Aims: The T-helper 1 (TH1) immune reaction is essential for the eradication of hepatitis $\mathrm{C}$ virus (HCV) during pegylated interferon $\alpha$ (PEG-IFN- $\alpha$ )- and ribavirin (RBV)-based therapy in chronic HCV patients. Secreted phosphoprotein 1 (SPP1) was shown to be a crucial cytokine for the initiation of a TH1 immune response. We aimed to investigate whether SPP1 single nucleotide polymorphisms (SNPs) may influence sustained virological response (SVR) rates. Methods: Two SNPs in the promoter region of SPP1 at the $-443 \mathrm{C}>\mathrm{T}$ and $-1748 \mathrm{G}>\mathrm{A}$ loci were genotyped in 100 patients with chronic HCV genotype 4 infection using a TaqMan SNP genotyping assay. Results: Sixty-seven patients achieved a SVR, and 33 patients showed no SVR. Patients carrying the T/T genotype at the -443 locus showed a significantly higher SVR rate than those carrying the $\mathrm{C} / \mathrm{T}$ or $\mathrm{C} / \mathrm{C}$ genotype $(83.67 \%$ vs $50.98 \%, p<0.001$ ). At the -1748 locus, the SVR rate was significantly higher in patients with the $G / G$ genotype than in those with the $\mathrm{A} / \mathrm{A}$ genotype $(88.89 \%$ vs $52.63 \%, \mathrm{p}=0.028$ ) and in patients with the $\mathrm{G} / \mathrm{A}$ genotype than in those with the A/A genotype ( $85.29 \%$ vs $52.63 \%, p=0.001)$. Conclusions: SPP1 SNPs at $-443 \mathrm{C}>\mathrm{T}$ and $-1748 \mathrm{G}>\mathrm{A}$ loci may be useful markers for predicting the response to PEG-IFN- $\alpha-2 b$ plus RBV therapy in Egyptian patients with chronic HCV genotype 4 infection. (Gut Liver 2015;9:516-524)
\end{abstract}

Key Words: Chronic hepatitis C; Interferons; Response; Secreted phosphoprotein 1; Single nucleotide polymorphisms

\section{INTRODUCTION}

Hepatitis C virus (HCV) represents a major worldwide public health problem. The World Health Organization estimated prevalence of HCV in Egypt, the largest reservoir of HCV in the world is $22 \% \%^{1,2}$ with HCV genotype 4 being the most prevalent genotype in the Middle East and Egypt where it accounts for $>80 \%$ of all HCV infections. ${ }^{3}$

The current standard of care treatment for patients with chronic HCV infection is a combination therapy with pegylated interferon- $\alpha$ (PEG-IFN- $\alpha$ ) 2a or 2b given by injection plus oral ribavirin (RBV), for 24 or 48 weeks, depending on HCV genotype. ${ }^{4}$ A sustained elimination of HCV is achieved if the HCV RNA remains negative 6 months after the end of treatment (sustained virological response, SVR). However, the PEG-IFN- $\alpha$ / RBV therapy failed to cure all patients who underwent the treatment. ${ }^{5}$

Much effort has been directed at identifying factors predictive of PEG-IFN- $\alpha /$ RBV responsiveness. Both viral and host factors have been shown to influence treatment outcomes. ${ }^{6}$ Several studies have demonstrated that the HCV genotype is the key determinant of response to PEG-IFN- $\alpha /$ RBV treatment. ${ }^{7}$ In addition, the baseline viral load is an important viral factor affecting the responsiveness. ${ }^{8}$ Furthermore, the efficacy of IFN-based therapies may be influenced by the T-helper 1 (TH1) immune reaction. ${ }^{9}$

Secreted phosphoprotein 1 (SPP1), also known as osteopontin (OPN), early T-lymphocyte activation protein 1 and bone sialoprotein I (BSP-I) is a multifunctional secreted glycosylated sialic acid-rich phosphoprotein functioning as a free proinflammatory cytokine in body fluids or as an immobilized noncollagenous extracellular matrix protein in mineralized tissues. ${ }^{10}$

OPN is a multifunctional molecule involved in a series of physiological and pathological processes. In addition, it regulates a diverse range of immunological responses such as antiinfectious and antitumor immune responses. ${ }^{11}$ Moreover, it is

Correspondence to: Mohamed A. M. Ali

Department of Biochemistry, Faculty of Science, Ain Shams University, Abbassia, Cairo 11566, Egypt

Tel: +20-100-646-7639, Fax: +20-2-26842123, E-mail: mohd_ali2@sci.asu.edu.eg

Received on April 25, 2014. Revised on August 4, 2014. Accepted on August 6, 2014. Published online February 26,2015

pISSN 1976-2283 eISSN 2005-1212 http://dx.doi.org/10.5009/gnl14162

@ This is an Open Access article distributed under the terms of the Creative Commons Attribution Non-Commercial License (http://creativecommons.org/licenses/by-nc/4.0) which permits unrestricted non-commercial use, distribution, and reproduction in any medium, provided the original work is properly cited. 
known to be critical for the efficient development of TH1 immune responses. ${ }^{12}$ It has been also shown that OPN is capable of inducing the TH1 and inhibiting the TH2 responses, upregulating interferon $\gamma$ and interleukin 12 production, while downregulating that of interleukin $10 .^{13}$

The human OPN gene (SPP1) is located on chromosome 4q21-q25 and encoding the OPN protein with 314 amino acid residues. ${ }^{14}$ OPN gene is a predominantly transcriptional regulated gene, and more than 10 single nucleotide polymorphisms (SNPs) have been identified in its promoter which may affect its expression level. Previously, three functional polymorphisms $(-66 \mathrm{~T} / \mathrm{G},-156 \mathrm{delG} / \mathrm{G}$, and $-443 \mathrm{~T} / \mathrm{C})$ in the promoter region of OPN gene have been found to affect its transcriptional activity ${ }^{15}$ and expression level. ${ }^{16}$

It is now well established that host genetic factors play a role in the response to IFN-based therapy in HCV infection. ${ }^{17}$ Several lines of evidence suggested that SNPs in the promoter of OPN gene appear to be risk factors for hepatitis activity ${ }^{18}$ and $\mathrm{SVR}^{19}$ in Japanese patients with chronic hepatitis C.

In an attempt to shed some light on the association of SPP1 genetic variants with SVR rates, we explored whether SNPs in the SPP1 promoter are associated with the response to PEG-IFN/ RBV in Egyptian patients with chronic HCV infection to identify more accurately the subset of non-SVR patients who may be candidates for intensive treatment in order to improve SVR rates.

\section{MATERIALS and METHODS}

\section{Study population}

One hundred newly diagnosed patients with chronic HCV genotype 4 infection who were referred to the outpatient clinic of the Hepatology unit, Internal Medicine Hospital, Armed Forces Medical Complex, Kobry Elqobba, Cairo, Egypt were enrolled in this prospective study. Diagnosis of chronic HCV infection ( $>6$ months) was confirmed by positive anti-HCV antibodies and detectable HCV RNA in serum. Inclusion criteria included adult patients aged $\geq 18$ years, detectable serum anti-HCV antibody, quantifiable serum HCV RNA and demonstration of compensated liver disease by clinical, biochemical and imaging findings. Patients were excluded from the study if they had other liver diseases, such as hepatitis A, hepatitis B, schistosomiasis, autoimmune hepatitis, alcoholic liver disease, drug induced hepatitis, decompensated liver disease or other comorbid conditions such as coinfection with human immunodeficiency virus, neoplastic disease, autoimmune disease, therapy with antiviral or immunomodulatory agents prior to referral. The study protocol was approved by the Scientific Ethical Committee of Faculty of Science, Ain Shams University. A written informed consent was obtained from all the enrolled patients prior to inclusion into the study in accordance with the Declaration of Helsinki.

\section{Treatment regimen}

Patients with chronic HCV genotype 4 infection were treated with the combined PEG-IFN- $\alpha /$ RBV therapy. ${ }^{20}$ PEG-IFN- $\alpha-2 b$ (Peg-Intron; Schering Plough Corp., Kenilworth, NJ, USA) was subcutaneously administered at a fixed dose of $1.5 \mu \mathrm{g} / \mathrm{kg} / \mathrm{wk}$ together with orally administered weight-based RBV (Rebetol; Schering Plough Corp.) at doses of $800 \mathrm{mg} /$ day for patients $<65$ $\mathrm{kg} ; 1,000 \mathrm{mg} /$ day for patients weighing 65 to $85 \mathrm{~kg} ; 1,200 \mathrm{mg} /$ day for patients weighing 85 to $105 \mathrm{~kg}$; and 1,400 mg/day for patients weighing $>105 \mathrm{~kg}$ but $<125 \mathrm{~kg}$ for 48 weeks. $^{21}$

\section{Serological investigations}

Serum HCV antibody (anti-HCV) was detected using a thirdgeneration enzyme immunoassay, Abbott AxSYM anti-HCV 3.0 (Abbott Laboratories, Abbott Park, IL, USA) according to the manufacturer's instructions. ${ }^{22}$

\section{HCV genotyping}

Serum HCV RNA was extracted using the QIAamp ${ }^{\circledR}$ Viral RNA Mini Kit (Qiagen, Hilden, Germany) according to the manufacturer's instructions. HCV genotype was detected by a reverse hybridization analysis (Versant ${ }^{\circledR}$ HCV Genotype 2.0 Line Probe Assay [LiPA]; Siemens Healthcare In Vitro Diagnostics, Tarrytown, NY, USA) according to the manufacturer's instructions. The HCV genotype nomenclature used in this study is that previously proposed by an international panel. ${ }^{23}$

\section{Biochemical investigations}

Serum samples were used for the determination of alanine aminotransferase (ALT), aspartate aminotransferase (AST), alkaline phosphatase (ALP), $\gamma$-glutamyltransferase (GGT), total bilirubin, total protein, and albumin levels using Dimension ${ }^{\circledR}$ RxL Max ${ }^{\circledR}$ Integrated Chemistry System (Siemens Healthcare Laboratory Diagnostics, Erlangen, Germany) according to the manufacturer's instructions.

\section{Quantitation of serum HCV RNA}

Viral RNA was extracted from serum samples using the QIAamp ${ }^{\circledR}$ Viral RNA Mini Kit according to the manufacturer's instructions. Quantitative assessment of HCV RNA level was performed by one-step real-time quantitative reverse transcription polymerase chain reaction (qRT-PCR) using the AgPath$\mathrm{ID}^{\mathrm{TM}}$ One-Step RT-PCR Kit and the HCV-Specific 25X Primer/ TaqMan ${ }^{\circledR}$ Probe Mix (Applied Biosystems, Foster City, CA, USA) as recommended by the manufacturer. The 7500 Fast Real-Time PCR System (Applied Biosystems) was used for real-time analysis.

\section{Virological response criteria and treatment endpoints}

A rapid virological response (RVR) is defined as undetectable HCV RNA in serum at week 4 of treatment. An early virological response is referred to as the absence of HCV RNA in serum 
at week 12 of therapy. An end of treatment response (ETR) is defined as an undetectable HCV RNA in serum at the end of the 48-week course of therapy. The primary endpoint is the sustained virological response (SVR) which is referred to as the complete absence of HCV RNA in serum 24 weeks following discontinuation of therapy. Virological relapse is defined as the reappearance of HCV RNA in serum at week 72 after treatment is discontinued and an ETR was documented. ${ }^{24}$

\section{Response assessment}

Patients were monitored during therapy to assess the response to treatment and for the occurrence of side effects. The clinical monitoring schedule consisted of monthly visits during the first 12 weeks of treatment followed by visits at 12 week intervals thereafter until the end of therapy. At each visit the patients were questioned regarding the presence of side effects and depression. They have also been queried about adherence to treatment. Laboratory monitoring included measurement of ALT, AST, ALP, GGT, total bilirubin, total protein, albumin, and HCV RNA levels at diagnosis before commencing PEG-IFN- $\alpha-2 b$ plus RBV combination treatment to establish a baseline measurement, at weeks 4 and 12 after commencing therapy, at the end of treatment (week 48), and at the end of follow-up (week 72).

\section{SPP1 SNPs analysis}

Genomic DNA was extracted from peripheral blood leukocytes using the QIAamp ${ }^{\circledR}$ DNA Blood Mini Kit (Qiagen) following the manufacturer's instructions. Two SNPs in the promoter region of SPP1 gene (National Center for Biotechnology Information reference sequence gene; NCBI RefSeq gene: NG_030362.1) at nucleotides -443 C $>$ T (rs11730582) and -1748 G>A (rs2728127) were genotyped using TaqMan SNP genotyping assay (rs11730582 assay ID: C_1840808_10; rs2728127 assay ID: C_1840806_10; Applied Biosystems) and the 7500 Fast Real-Time PCR System following manufacturer's instructions. ${ }^{25}$

\section{Statistical analysis}

Continuous variables were expressed as mean \pm standard deviation (SD) and compared using independent Student t-test (for 2 groups) or one-way analysis of variance (for $>2$ groups) as appropriate. Categorical variables were expressed as the number of cases (percentage) and compared using the Pearson chi-square test. A per-protocol analysis that restricts the comparison to the ideal patients (patients who adhered perfectly to the study protocol in terms of eligibility and treatment evaluation criteria has been applied in this study). Univariate and multivariate logistic regression analyses were used to identify independent predictive factors influencing SVR rate. Variables achieving statistical significance according to univariate analysis were subsequently included into multivariate analysis using a logistic regression model. For all statistical tests, p-values were two-sided, and a p-value of less than 0.05 was considered statistically significant.
Data statistical analyses were performed using the SPSS software version 20.0 (SPSS Inc., Chicago, IL, USA). ${ }^{26}$ Genotypes, alleles and haplotypes frequency was estimated. Genotype frequencies at each SPP1 gene locus were compared with the frequencies expected by the Hardy-Weinberg equilibrium (HWE) using a chi-square goodness of fit test. Pairwise linkage disequilibrium (LD) between the 2 SPP1 gene loci was assessed by estimating the coefficients of $\mathrm{LD}\left(\mathrm{D}^{\prime}\right.$, standardized disequilibrium; $r^{2}$, square of the correlation coefficient). ${ }^{27}$ All genetic analyses were performed using the genetic analysis in Excel 6.5 (GenAlEx 6.5) software. ${ }^{28,29}$

\section{RESULTS}

\section{Baseline demographic and clinical characteristics of the patients}

The study cohort was composed of a total of 100 Egyptian patients with chronic HCV genotype 4 infection. The demographic and clinical features of the patients at diagnosis are listed in Table 1.

\section{Efficacy of the combined PEG-IFN- $\alpha-2 b / R B V$ therapy}

Patients were classified into two groups: SVR group and nonSVR group based on treatment outcome. Virological response rates are shown in Table 2. Of the 100 patients treated with PEG-IFN- $\alpha-2 b / R B V, 67$ patients achieved SVR and 33 patients revealed no SVR. The current study revealed an overall SVR rate of $67 \%$ with an overall relapse rate of 20.24\%. Patients of both SVR and non-SVR groups showed no significant dif-

Table 1. Demographic and Clinical Features of the 100 Patients

\begin{tabular}{lc}
\hline \multicolumn{1}{c}{ Characteristic } & Value \\
\hline Gender & 62 \\
Male, \% & 38 \\
Female, \% & $45.2 \pm 8$ \\
Age, yr & $79.6 \pm 6.6$ \\
ALT, IU/L & $71.2 \pm 9$ \\
AST, IU/L & $100.4 \pm 23.2$ \\
ALP, IU/L & $75 \pm 10.1$ \\
GGT, IU/L & $1 \pm 0.2$ \\
Total bilirubin, mg/dL & $6.8 \pm 0.7$ \\
Total protein, g/dL & $3.6 \pm 0.2$ \\
Albumin, g/dL & \\
HCV RNA levels, IU/mL & 59 \\
$\leq 800,000, \%$ & 41 \\
$>800,000, \%$ &
\end{tabular}

Data are presented as mean \pm SD unless otherwise indicated.

ALT, alanine aminotransferase; AST, aspartate aminotransferase; ALP, alkaline phosphatase; GGT, $\gamma$-glutamyltransferase; HCV, hepatitis $\mathrm{C}$ virus. 
Table 2. Rates of Virological Responses of the 100 Patients

\begin{tabular}{|c|c|c|c|c|}
\hline \multirow{2}{*}{ Virological response } & \multirow{2}{*}{ Patients } & \multicolumn{2}{|c|}{ HCV RNA levels } & \multirow{2}{*}{ p-value } \\
\hline & & $\leq 800,000 \mathrm{IU} / \mathrm{mL}(\mathrm{n}=59)$ & $>800,000 \mathrm{IU} / \mathrm{mL}(\mathrm{n}=41)$ & \\
\hline \multirow[t]{2}{*}{ RVR } & 51 & 45 & 6 & $<0.001^{*}$ \\
\hline & (51) & (76.3) & $(14.6)$ & \\
\hline \multirow[t]{2}{*}{ EVR } & 91 & 58 & 33 & $0.002^{\dagger}$ \\
\hline & (91) & (98.3) & $(80.5)$ & \\
\hline \multirow[t]{2}{*}{ ETR } & 84 & 57 & 27 & $<0.001^{*}$ \\
\hline & (84) & (96.6) & (65.9) & \\
\hline \multirow[t]{2}{*}{ SVR } & 67 & 55 & 12 & $<0.001^{*}$ \\
\hline & (67) & $(93.2)$ & (29.3) & \\
\hline \multirow[t]{2}{*}{ Relapse } & $17 / 84$ & $2 / 57$ & $15 / 27$ & $<0.001^{*}$ \\
\hline & $(20.2)$ & (3.5) & (55.6) & \\
\hline
\end{tabular}

Data are presented as number (\%).

HCV, hepatitis C virus; RVR, rapid virological response; EVR, early virological response; ETR, end of treatment response; SVR, sustained virological response.

*Indicates a highly statistically significant difference; ${ }^{\dagger}$ Indicates a very statistically significant difference.

Table 3. Pre- and Posttreatment Demographic and Clinical Characteristics of the Patients in Both the Sustained Virological Response (SVR) and Non-SVR Groups

\begin{tabular}{|c|c|c|c|c|c|c|}
\hline \multirow[b]{2}{*}{ Characteristic } & \multicolumn{3}{|c|}{ Pretreatment } & \multicolumn{3}{|c|}{ Posttreatment } \\
\hline & $\begin{array}{c}\text { SVR } \\
(\mathrm{n}=67)\end{array}$ & $\begin{array}{c}\text { Non-SVR } \\
(\mathrm{n}=33)\end{array}$ & p-value & $\begin{array}{c}\text { SVR } \\
(\mathrm{n}=67)\end{array}$ & $\begin{array}{c}\text { Non-SVR } \\
(\mathrm{n}=33)\end{array}$ & $\mathrm{p}$-value \\
\hline Gender, no. (\%) & & & 0.84 & & & - \\
\hline Male & $42(62.7)$ & $20(60.6)$ & & - & - & \\
\hline Female & $25(37.3)$ & $13(39.4)$ & & - & - & \\
\hline Age, yr & $44.3 \pm 8.2$ & $47.1 \pm 7.1$ & 0.09 & - & - & - \\
\hline ALT, IU/L & $78.9 \pm 6.3$ & $81.2 \pm 7$ & 0.11 & $45.9 \pm 5.8$ & $79.5 \pm 13$ & $<0.001^{*}$ \\
\hline AST, IU/L & $70.3 \pm 9.2$ & $72.9 \pm 8.6$ & 0.19 & $43.2 \pm 6.6$ & $70 \pm 11.9$ & $<0.001^{*}$ \\
\hline ALP, IU/L & $98.4 \pm 24.2$ & $104.6 \pm 21$ & 0.2 & $67.5 \pm 18.4$ & $101.6 \pm 25.8$ & $<0.001^{*}$ \\
\hline GGT, IU/L & $74.3 \pm 10.2$ & $76.6 \pm 9.8$ & 0.29 & $47.7 \pm 13.7$ & $71.2 \pm 14.7$ & $<0.001^{*}$ \\
\hline Total bilirubin, mg/dL & $1 \pm 0.2$ & $1.1 \pm 0.2$ & 0.06 & $0.6 \pm 0.2$ & $0.9 \pm 0.2$ & $<0.001^{*}$ \\
\hline Total protein, g/dL & $6.9 \pm 0.7$ & $6.6 \pm 0.6$ & 0.06 & $7.3 \pm 0.7$ & $6.8 \pm 0.7$ & $0.001^{\dagger}$ \\
\hline Albumin, g/dL & $3.6 \pm 0.2$ & $3.5 \pm 0.2$ & 0.07 & $4 \pm 0.2$ & $3.7 \pm 0.3$ & $<0.001^{*}$ \\
\hline HCV RNA levels, IU/mL & $766,942 \pm 235,767.8$ & $972,670.4 \pm 392,823$ & $0.002^{\dagger}$ & $0.0 \pm 0.0$ & $11,689 \pm 5,120$ & $<0.001^{*}$ \\
\hline
\end{tabular}

Data are presented as mean \pm SD unless otherwise indicated.

ALT, alanine aminotransferase; AST, aspartate aminotransferase; ALP, alkaline phosphatase; GGT, $\gamma$-glutamyltransferase; HCV, hepatitis C virus. *Indicates a highly statistically significant difference; ${ }^{\dagger}$ Indicates a very statistically significant difference.

ference regarding pretreatment characteristics (gender, age at diagnosis, ALT, AST, ALP, GGT, total bilirubin, total protein, or albumin; $>>0.05$ ). Notably, among pretreatment features, baseline HCV viral load appeared to discriminate responders from nonresponders $(\mathrm{p}=0.002)$. On the other hand, there were highly significant differences in the posttreatment levels of ALT, AST, ALP, GGT, total bilirubin, total protein, albumin, and HCV RNA levels between the patients of both SVR and non-SVR groups. The pretreatment and posttreatment (at the end of follow-up; week 72) patient characteristics of both SVR and non-SVR groups are summarized in Table 3.

\section{SNPs in the promoter region of SPP1}

Genotype distributions and allele frequencies of SPP1 SNPs at -443 and -1748 loci are presented in Table 4. Regarding -443 C/T SNP, patients with SVR had a significantly higher frequency of the $\mathrm{T}$ allele as compared to the non-SVR patients indicating that patients who carried the T allele (the favorable allele) were more likely to achieve SVR as compared to carriers of the C allele $(p<0.001)$. In regard to the SNP at the $-1748 \mathrm{G} / \mathrm{A}$ locus, 
Table 4. Genotype Distribution and Allele Frequency of Single Nucleotide Polymorphisms in the Promoter Region of SPP1 in Patients with Chronic Hepatitis C Virus Infection in Both the Sustained Virological Response (SVR) and Non-SVR Groups

\begin{tabular}{|c|c|c|c|c|c|}
\hline \multirow{2}{*}{ Locus } & \multicolumn{3}{|c|}{ Genotype distribution } & \multicolumn{2}{|c|}{ Allele frequency } \\
\hline & $\begin{array}{c}\mathrm{C} / \mathrm{C} \\
\text { Homozygotes }\end{array}$ & $\begin{array}{c}\mathrm{C} / \mathrm{T} \\
\text { Heterozygotes }\end{array}$ & $\begin{array}{c}\mathrm{T} / \mathrm{T} \\
\text { Homozygotes }\end{array}$ & C allele & $\mathrm{T}$ allele \\
\hline \multicolumn{6}{|l|}{$-443 \mathrm{C}>\mathrm{T}^{*}$} \\
\hline Patients $(\mathrm{n}=100)$ & $14(14.0)$ & 37 (37.0) & $49(49.0)$ & $65(32.5)$ & $135(67.5)$ \\
\hline \multicolumn{6}{|l|}{ Groups } \\
\hline SVR $(n=67)$ & $1(1.5)$ & $25(37.3)$ & $41(61.2)$ & $27(20.2)$ & 107 (79.9) \\
\hline Non-SVR (n=33) & $13(39.4)$ & $12(36.4)$ & $8(24.2)$ & 38 (57.6) & $28(42.4)$ \\
\hline \multirow[t]{2}{*}{$\mathrm{p}$-value } & $<0.001^{\ddagger}$ & 0.926 & $<0.001^{\ddagger}$ & $<0.001^{\ddagger}$ & $<0.001^{\ddagger}$ \\
\hline & $\begin{array}{c}\mathrm{G} / \mathrm{G} \\
\text { Homozygotes }\end{array}$ & $\begin{array}{c}\text { G/A } \\
\text { Heterozygotes }\end{array}$ & $\begin{array}{c}\text { A/A } \\
\text { Homozygotes }\end{array}$ & G allele & A allele \\
\hline \multicolumn{6}{|l|}{$-1748 \mathrm{G}>\mathrm{A}^{\dagger}$} \\
\hline Patients $(n=100)$ & $9(9.0)$ & $34(34.0)$ & $57(57.0)$ & $52(26.0)$ & $148(74.0)$ \\
\hline \multicolumn{6}{|l|}{ Groups } \\
\hline SVR $(n=67)$ & $8(11.9)$ & $29(43.3)$ & $30(44.8)$ & 45 (33.6) & 89 (66.4) \\
\hline Non-SVR (n=33) & $1(3.0)$ & $5(15.2)$ & 27 (81.8) & $7(10.6)$ & $59(89.4)$ \\
\hline$p$-value & 0.111 & $0.004^{\S}$ & $<0.001^{\ddagger}$ & $0.009^{\S}$ & $0.009^{\S}$ \\
\hline
\end{tabular}

Data are presented as number (\%).

SPP1, secreted phosphoprotein 1.

${ }^{*}$ Position, promoter; ref SNP ID, rs11730582; ${ }^{\dagger}$ Position, promoter; ref SNP ID, rs2728127; ${ }^{\ddagger}$ Indicates a highly statistically significant difference; ${ }^{5}$ Indicates a very statistically significant difference.

patients with SVR had a significantly higher frequency of the favorable allele (G allele) as compared to the non-SVR patients.

The relationship between SPP1 SNP genotypes and virological response rates is shown in Table 5 . Concerning the $-443 \mathrm{C} / \mathrm{T}$ locus, the SVR rate was significantly higher in patients with $\mathrm{T} / \mathrm{T}$ genotype than in those with $\mathrm{C} / \mathrm{C}$ genotype. In addition, the SVR rate was higher in patients with $\mathrm{T} / \mathrm{T}$ genotype than in those with $\mathrm{C} / \mathrm{T}$ genotype, but this difference did not reach statistical significance. Moreover, the SVR rate was also significantly higher in patients with $\mathrm{C} / \mathrm{T}$ genotype than in those with $\mathrm{C} / \mathrm{C}$ genotype. Surprisingly, patients carrying the TT genotype showed a significantly higher SVR rate than those carrying CT or CC genotype (83.7\% vs 51.0\%, p<0.001). Regarding the -1748 G/A SNP, the SVR rate was significantly higher in patients with $\mathrm{G} / \mathrm{G}$ genotype than in those with A/A genotype. Moreover, the SVR rate was significantly higher in patients with G/A genotype than in those with A/A genotype. On the other hand, the SVR rate did not differ significantly between patients with $\mathrm{G} / \mathrm{G}$ and $\mathrm{G} / \mathrm{A}$ genotypes. Interestingly, patients with GG or GA genotype achieved SVR at significantly higher rates than those with AA genotype (86.1\% vs $52.6 \%, \mathrm{p}<0.001)$.

Baseline demographic and clinical characteristics did not differ significantly between patients with CC, CT, and TT genotypes ( $p>0.05$ ). Moreover, there were no statistically significant differences between patients with GG, GA, and AA genotypes regarding gender, age, and baseline levels of ALT, AST, ALP, GGT, total bilirubin, total protein, and albumin ( $p>0.05$ ). On the other hand, the mean \pm SD of baseline HCV RNA levels were $1,036,355 \pm 483,463,805,791 \pm 312,998$, and 799,184 $\pm 219,609$ $\mathrm{IU} / \mathrm{mL}$ for the CC, CT, and TT genotypes at the $-443 \mathrm{C} / \mathrm{T}$ locus, respectively (CC vs others, $p=0.008$; CT vs others, $p=0.476$; TT vs others, $p=0.262$ ). Similarly, for the $-1748 \mathrm{G} / \mathrm{A}$ locus, the baseline HCV RNA levels (mean \pm SD) were 757,495 $\pm 112,069$, $795,405 \pm 218,453$, and $870,562 \pm 370,513 \mathrm{IU} / \mathrm{mL}$ for the GG, GA, and AA genotypes, respectively (GG vs others, $p=0.436$; GA vs others, $p=0.365$; AA vs others, $p=0.187$ ).

The expected genotype frequencies of the $-443 \mathrm{C} / \mathrm{T}$ SNP were 10.6\%, 43.9\%, and 45.6\% for genotypes CC, CT, and TT, respectively. Moreover, the expected genotype frequencies of the -1748 G/A SNP were 6.8\%, 38.5\%, and 54.8\% for genotypes GG, GA, and AA, respectively. The distribution of the observed genotypes was not significantly different from the expected distribution according to HWE for both loci $\left(-443: \chi^{2}=2.455\right.$, $\left.\mathrm{p}=0.117 ;-1748: \chi^{2}=1.355, \mathrm{p}=0.244\right)$. Pairwise LD between the two SPP1 gene polymorphisms was calculated by estimating the coefficients of $L D\left(D^{\prime} ; r^{2}\right)$. The two SNPs $(-443 \mathrm{C}>\mathrm{T}$ and -1748 $\mathrm{G}>A)$ showed a significant $\left(\mathrm{D}^{\prime}=1 ; \mathrm{p}<0.001\right)$ but weak $\left(\mathrm{r}^{2}=0.169\right)$ LD to each other.

As reported in Table 6, analysis of the two SPP1 SNPs forming 4 haplotypes (Ht 1: CG; Ht 2: CA; Ht 3: TG; Ht 4: TA). Interestingly, patients who carried the TG haplotype were more likely to achieve SVR as compared to carriers of the CA haplotype $(\mathrm{p}<0.001)$.

Univariate and multivariate logistic regression analyses were 
Table 5. Relationship between SPP1 Single Nucleotide Polymorphism Genotypes and Rates of Virological Response to PEG-IFN- $\alpha-2 b /$ RBV in 100 Patients with Chronic Hepatitis C Virus Infection

\begin{tabular}{|c|c|c|c|c|c|c|c|c|}
\hline \multirow{2}{*}{$\begin{array}{l}\text { Virological } \\
\text { response }\end{array}$} & \multicolumn{3}{|c|}{ rs11730582 $(-443 \mathrm{C}>\mathrm{T})$} & \multirow{2}{*}{$\begin{array}{c}\mathrm{p} \text {-value } \\
\text { (C/C vs } \mathrm{C} / \mathrm{T} \\
\mathrm{C} / \mathrm{C} \text { vs } \mathrm{T} / \mathrm{T} \\
\mathrm{C} / \mathrm{T} \text { vs } \mathrm{T} / \mathrm{T})\end{array}$} & \multicolumn{3}{|c|}{ rs2728127 (-1748 G>A) } & \multirow{2}{*}{$\begin{array}{c}\text { p-value } \\
\text { (G/G vs } G / A \\
\text { G/G vs } A / A \\
\text { G/A vs } A / A)\end{array}$} \\
\hline & $\begin{array}{c}C / C \\
(n=14)\end{array}$ & $\begin{array}{c}\mathrm{C} / \mathrm{T} \\
(\mathrm{n}=37)\end{array}$ & $\begin{array}{c}\mathrm{T} / \mathrm{T} \\
(\mathrm{n}=49)\end{array}$ & & $\begin{array}{c}\mathrm{G} / \mathrm{G} \\
(\mathrm{n}=9)\end{array}$ & $\begin{array}{c}\mathrm{G} / \mathrm{A} \\
(\mathrm{n}=34)\end{array}$ & $\begin{array}{c}\mathrm{A} / \mathrm{A} \\
(\mathrm{n}=57)\end{array}$ & \\
\hline \multirow[t]{3}{*}{$\operatorname{RVR}(\mathrm{n}=51)$} & \multirow{3}{*}{$\begin{array}{c}2 \\
(14.3)\end{array}$} & \multirow{3}{*}{$\begin{array}{c}14 \\
(37.8)\end{array}$} & \multirow{3}{*}{$\begin{array}{c}35 \\
(71.4)\end{array}$} & 0.089 & \multirow{3}{*}{$\begin{array}{c}7 \\
(77.8)\end{array}$} & \multirow{3}{*}{$\begin{array}{c}25 \\
(73.5)\end{array}$} & \multirow{3}{*}{$\begin{array}{c}19 \\
(33.3)\end{array}$} & 0.793 \\
\hline & & & & $<0.001^{*}$ & & & & $0.011^{\ddagger}$ \\
\hline & & & & $0.002^{\dagger}$ & & & & $<0.001^{*}$ \\
\hline \multirow[t]{3}{*}{ EVR $(n=91)$} & \multirow{3}{*}{$\begin{array}{c}11 \\
(78.6)\end{array}$} & \multirow{3}{*}{$\begin{array}{c}33 \\
(89.2)\end{array}$} & \multirow{3}{*}{$\begin{array}{c}47 \\
(95.9)\end{array}$} & 0.343 & \multirow{3}{*}{$\begin{array}{c}9 \\
(100.0)\end{array}$} & \multirow{3}{*}{$\begin{array}{c}32 \\
(94.1)\end{array}$} & \multirow{3}{*}{$\begin{array}{c}50 \\
(87.7)\end{array}$} & 0.326 \\
\hline & & & & 0.055 & & & & 0.140 \\
\hline & & & & 0.227 & & & & 0.306 \\
\hline \multirow[t]{3}{*}{ ETR $(n=84)$} & \multirow{3}{*}{$\begin{array}{c}8 \\
(57.1)\end{array}$} & \multirow{3}{*}{$\begin{array}{c}31 \\
(83.8)\end{array}$} & \multirow{3}{*}{$\begin{array}{c}45 \\
(91.8)\end{array}$} & 0.053 & \multirow{3}{*}{$\begin{array}{c}9 \\
(100.0)\end{array}$} & \multirow{3}{*}{$\begin{array}{c}33 \\
(97.1)\end{array}$} & \multirow{3}{*}{$\begin{array}{c}42 \\
(73.7)\end{array}$} & 0.490 \\
\hline & & & & $0.004^{\dagger}$ & & & & $0.025^{\ddagger}$ \\
\hline & & & & 0.251 & & & & $0.002^{\dagger}$ \\
\hline \multirow[t]{3}{*}{ SVR $(n=67)$} & \multirow{3}{*}{$\begin{array}{c}1 \\
(7.1)\end{array}$} & \multirow{3}{*}{$\begin{array}{c}25 \\
(67.6)\end{array}$} & \multirow{3}{*}{$\begin{array}{c}41 \\
(83.7)\end{array}$} & $<0.001^{*}$ & \multirow{3}{*}{$\begin{array}{c}8 \\
(88.9)\end{array}$} & \multirow{3}{*}{$\begin{array}{c}29 \\
(85.3)\end{array}$} & \multirow{3}{*}{$\begin{array}{c}30 \\
(52.6)\end{array}$} & 0.777 \\
\hline & & & & $<0.001^{*}$ & & & & $0.028^{\ddagger}$ \\
\hline & & & & 0.081 & & & & $0.001^{\dagger}$ \\
\hline \multirow[t]{3}{*}{ Relapse $(\mathrm{n}=17)$} & \multirow{3}{*}{$\begin{array}{c}7 \\
(50.0)\end{array}$} & \multirow{3}{*}{$\begin{array}{c}6 \\
(16.2)\end{array}$} & & $<0.001^{*}$ & 1 & 4 & 12 & 0.933 \\
\hline & & & $(8)$ & $<0.001^{*}$ & $(111)$ & $(118)$ & 12 & 0.242 \\
\hline & & & & 0.189 & $(11.1)$ & (11.8) & $(21.1)$ & 0.077 \\
\hline
\end{tabular}

Data are presented as number (\%).

SPP1, secreted phosphoprotein 1; PEG-IFN- $\alpha$-2b, pegylated interferon $\alpha-2 b$; RBV, ribavirin; RVR, rapid virological response; EVR, early virological response; ETR, end of treatment response; SVR, sustained virological response.

${ }^{*}$ Indicates a highly statistically significant difference; ${ }^{\dagger}$ Indicates a very statistically significant difference; ${ }^{\ddagger}$ Indicates a statistically significant difference.

Table 6. Association of SPP1 Haplotypes with Sustained Virological Response in 100 Patients with Chronic Hepatitis C Virus infection

\begin{tabular}{|c|c|c|c|c|c|c|c|}
\hline \multirow{2}{*}{ Haplotype } & \multirow{2}{*}{$-443 \mathrm{C}>\mathrm{T}$} & \multirow{2}{*}{$-1748 \mathrm{G}>\mathrm{A}$} & \multicolumn{3}{|c|}{ Haplotype frequency } & \multirow{2}{*}{$\chi^{2}$} & \multirow{2}{*}{$\mathrm{p}$-value } \\
\hline & & & Patients & SVR $(n=67)$ & Non-SVR $(n=33)$ & & \\
\hline Ht 1: CG & $\mathrm{C}$ & G & 0 & 0 & 0 & - & - \\
\hline Ht 2: CA & $\mathrm{C}$ & A & 65 (32.5) & $27(20.1)$ & 38 (57.6) & 28.235 & $<0.001^{*}$ \\
\hline Ht 3: TG & $\mathrm{T}$ & G & $52(26.0)$ & 45 (33.6) & 7 (10.6) & 12.133 & $<0.001^{*}$ \\
\hline Ht 4: TA & $\mathrm{T}$ & $\mathrm{A}$ & 83 (41.5) & $62(46.3)$ & 21 (31.8) & 3.803 & 0.051 \\
\hline
\end{tabular}

Data are presented as number (\%).

SPP1, secreted phosphoprotein 1; SVR, sustained virological response; Ht, haplotype.

*Indicates a highly statistically significant difference.

performed to identify factors that might contribute to SVR in patients with chronic HCV. Demographic features, pretreatment clinical characteristics and genotypes of SPP1 SNPs (-443 C>T and $-1748 \mathrm{G}>\mathrm{A}$ ) were included as possible predictive factors in univariate analysis. As shown in Table 7, pretreatment HCV RNA level, CC and TT homozygotes of -443 C $>$ T SNP, GA heterozygotes and AA homozygotes of $-1748 \mathrm{G}>\mathrm{A}$ SNP were found to be significant variables in univariate analysis with $\mathrm{p}$ values of $<0.001,<0.001,0.001,0.008$, and 0.001, respectively. The significant variables that were in favor of achieving SVR (pretreatment HCV RNA level, p<0.001; TT homozygotes among genotypes of $-443 \mathrm{C}>\mathrm{T}$ SNP, $\mathrm{p}=0.001$; and GA heterozygotes among genotypes of $-1748 \mathrm{G}>\mathrm{A}$ SNP, $\mathrm{p}=0.008$ ) were selected as predictor variables, and multivariate analysis was performed stepwise. Consequently, pretreatment HCV RNA level (odds ratio [OR], 43.308; 95\% confidence interval [CI], 10.829 to 173.196 ; $\mathrm{p}<0.001$ ) and TT homozygotes of $-443 \mathrm{C}>\mathrm{T}$ SNP (OR, 7.547; 95\% CI, 2.01 to 28.334; $p=0.003$ ) were identified as independent predictive factors for SVR (Table 7).

\section{DISCUSSION}

Since the initial use of IFN to treat HCV infection, much effort has been directed at identifying factors predictive of treatment 
Table 7. Univariate and Multivariate Logistic Regression Analyses of Factors Influencing Sustained Virological Response to PEG-IFN- $\alpha-2 b / R B V$ in 100 Patients with Chronic Hepatitis C Virus Infection

\begin{tabular}{|c|c|c|c|}
\hline Variable & p-value & OR & 95\% CI (lower-upper) \\
\hline \multicolumn{4}{|l|}{ Univariate logistic regression analysis } \\
\hline Gender (male vs female) & 0.840 & 0.916 & $0.389-2.155$ \\
\hline Age at diagnosis & 0.094 & 1.049 & $0.992-1.109$ \\
\hline Pretreatment ALT level & 0.109 & 1.057 & $0.988-1.131$ \\
\hline Pretreatment AST level & 0.185 & 1.033 & $0.985-1.083$ \\
\hline Pretreatment ALP level & 0.215 & 1.011 & $0.994-1.029$ \\
\hline Pretreatment GGT level & 0.283 & 1.023 & $0.981-1.066$ \\
\hline Pretreatment total bilirubin level & 0.065 & 7.242 & $0.888-59.086$ \\
\hline Pretreatment total protein level & 0.063 & 0.557 & $0.301-1.033$ \\
\hline Pretreatment albumin level & 0.077 & 0.156 & $0.020-1.223$ \\
\hline Pretreatment HCV RNA level $(\leq 800,000 \mathrm{IU} / \mathrm{mL}$ vs $>800,000 \mathrm{IU} / \mathrm{mL})$ & $<0.001^{*}$ & 0.030 & $0.009-0.102$ \\
\hline-443 (CC vs others) & $<0.001^{*}$ & 0.023 & $0.003-0.189$ \\
\hline-443 (CT vs others) & 0.926 & 1.042 & $0.439-2.474$ \\
\hline-443 (TT vs others) & $0.001^{\dagger}$ & 4.928 & $1.934-12.559$ \\
\hline-1748 (GG vs others) & 0.175 & 4.339 & $0.519-36.254$ \\
\hline-1748 (GA vs others) & $0.008^{\dagger}$ & 4.274 & $1.470-12.425$ \\
\hline-1748 (AA vs others) & $0.001^{\dagger}$ & 0.180 & $0.066-0.493$ \\
\hline \multicolumn{4}{|l|}{ Multivariate logistic regression analysis (stepwise method) } \\
\hline Pretreatment HCV RNA level $(\leq 800,000$ vs >800,000 IU/mL) & $<0.001^{*}$ & 43.308 & $10.829-173.196$ \\
\hline-443 (TT vs others) & $0.003^{\dagger}$ & 7.547 & $2.01-28.334$ \\
\hline-1748 (GA vs others) & 0.95 & 1.063 & $0.159-7.12$ \\
\hline
\end{tabular}

PEG-IFN- $\alpha-2 b$, pegylated interferon $\alpha-2 b$; RBV, ribavirin; OR, odds ratio; CI, confidence interval; ALT, alanine aminotransferase; AST, aspartate aminotransferase; ALP, alkaline phosphatase; GGT, $\gamma$-glutamyltransferase; HCV, hepatitis C virus.

*Indicates a highly statistically significant difference; Indicates a very statistically significant difference.

response. Several studies showed that low levels of pretreatment serum HCV RNA and the presence of viral genotype other than 1 were reported to be associated with favorable response to PEG-IFN/RBV therapy.

Accumulating evidence supports a critical role of host genetics in immune responses. ${ }^{30}$ Considering that the TH1 response is involved in the development of inflammation in chronic hepatitis $\mathrm{C}^{31}$ the hepatocytes infected with HCV are eradicated by TH1 response during IFN-based therapies, ${ }^{32}$ and that SPP1 is shown to be essential for initiation of TH1 immune response, ${ }^{13}$ the SNPs in SPP1 promoter may be crucial in provoking diverse TH1 immune reactions against HCV through the regulation of OPN expression in the liver.

In the current study, the genotype frequencies at $-443 \mathrm{C} / \mathrm{T}$ and $-1748 \mathrm{G} / \mathrm{A}$ loci differed from those reported by Mochida et al. ${ }^{18}$ and Naito et al. ${ }^{19}$ in Japanese patients with chronic hepatitis C. This apparent inconsistency may be due, in part, to differences in the genetic polymorphism distributions in different ethnic groups.

In the present study, the prevalence of SNP at nucleotides -443 C>T and -1748 G/A differed between patients in the SVR group and those in the non-SVR group. It is noteworthy that patients with SVR had a significantly higher frequency of the favorable allele ( $\mathrm{T}$ allele) as compared to the non-SVR patients $(\mathrm{p}<0.001)$, which might underlie their high rate of SVR. Therefore, we suggested that homozygosity for the $\mathrm{T}$ allele of the -443 C>T SNP is correlated with a better response to PEG-IFN/ RBV treatment, while the unfavorable $C$ allele-positive patients are poor responders. Unexpectedly, patients with SVR had a significantly higher frequency of the favorable allele ( $G$ allele) at the $-1748 \mathrm{G} / \mathrm{A}$ locus as compared to the non-SVR patients $(p=0.009)$, indicating that patients who were homozygous for the G allele were more likely to achieve SVR as compared to carriers of the unfavorable A allele.

The findings of the current study are in accordance with those reported by Naito et al., ${ }^{19}$ who suggested that OPN promoter SNPs at -443 and -1748 nucleotides were associated with SVR to IFN-based therapies in Japanese patients with chronic hepatitis $\mathrm{C}$.

It is worth noting that patients who carried the TG haplotype in the present study were more likely to achieve SVR as compared to carriers of the CA haplotype $(\mathrm{p}<0.001)$, suggesting that carriage of two SPP1 favorable alleles strongly, but not fully, predicted SVR, while carriage of one or two unfavorable al- 
leles did not completely predict failure to respond to treatment. One possibility is that haplotypes CA and TG directly affect the transcription, maturation, or stability of the OPN mRNA. Alternatively, they can be in $\mathrm{LD}$ with unidentified variations controlling OPN production.

Since SNP at nucleotide -443 is locating at 13 bp-upstream of the cis-acting enhancing element of human OPN, such SNP can affect the expression of OPN in the liver and may diverse immunological response against HCV infection. ${ }^{33}$ To the best of our knowledge, no functional studies have been carried out with the SPP1 -1748 A>G SNP. Thus, the mechanism by which polymorphisms within this locus influence the treatment outcome has not been established so far, although further functional studies are needed to address this issue.

In the present study, the baseline viral load in patients with CC genotype was significantly higher than in those with CT or TT genotype, an observation that might explain the finding that patients carrying the TT genotype showed a significantly higher SVR rate than those carrying CT or CC genotype. Also, the baseline viral load in the AA group was slightly but not significantly higher than that in the GA or GG, an observation that was in line with the finding that patients with GG or GA genotype achieved SVR at significantly higher rates than those with AA genotype.

In multivariate logistic regression analysis, pretreatment $\mathrm{HCV}$ RNA level and TT homozygotes of -443 C > T SNP were identified as significant independent predictors of SVR. Previously, Mochida et al. ${ }^{18}$ reported that in multivariate logistic regression analysis, -443 C>T SNP was selected as a significant variable reflecting hepatitis activity in Japanese patients with chronic hepatitis $\mathrm{C}$.

In conclusion, we have shown that two SNPs in the promoter region of SPP1 ( $-443 \mathrm{C}>\mathrm{T}$ and $-1748 \mathrm{G}>\mathrm{A})$ provide important independent information about a patient's likelihood of achieving SVR and may be an early predictor of the efficacy of IFNbased therapies in patients with chronic hepatitis C. This study established a predictive role of $S P P 1$ variants in detecting the treatment outcome in PEG-IFN/RBV-treated chronic hepatitis C patients and may help identifying a population that would benefit from intensified therapy as well as estimating the optimal duration of therapy.

Further in-depth molecular, genetic, and functional analyses are necessary to gain additional insights into the mechanism by which SPP1 variants affect the treatment outcome and whether this effect is realized at the transcriptional or posttranscriptional level to design a more optimal, tailor-made treatment regimen for each patient in clinical practice in the near future.

\section{CONFLICTS OF INTEREST}

No potential conflict of interest relevant to this article was reported.

\section{REFERENCES}

1. World Health Organization. Hepatitis C fact sheet, No. 164 [Internet]. Geneva: World Health Organization; 2011 [cited 2013 Apr 25]. Available from: http://www.who.int/mediacentre/factsheets/ fs164/en/.

2. Te HS, Jensen DM. Epidemiology of hepatitis B and C viruses: a global overview. Clin Liver Dis 2010;14:1-21.

3. Khattab MA, Ferenci P, Hadziyannis SJ, et al. Management of hepatitis $\mathrm{C}$ virus genotype 4: recommendations of an international expert panel. J Hepatol 2011;54:1250-1262.

4. Hadziyannis SJ, Sette H Jr, Morgan TR, et al. Peginterferonalpha2a and ribavirin combination therapy in chronic hepatitis C: a randomized study of treatment duration and ribavirin dose. Ann Intern Med 2004;140:346-355.

5. Backus LI, Boothroyd DB, Phillips BR, Belperio P, Halloran J, Mole LA. A sustained virologic response reduces risk of all-cause mortality in patients with hepatitis C. Clin Gastroenterol Hepatol 2011; 9:509-516.e1.

6. Kau A, Vermehren J, Sarrazin C. Treatment predictors of a sustained virologic response in hepatitis B and C. J Hepatol 2008;49: 634-651.

7. Hnatyszyn HJ. Chronic hepatitis $\mathrm{C}$ and genotyping: the clinical significance of determining HCV genotypes. Antivir Ther 2005;10: $1-11$.

8. Berg T, Sarrazin C, Herrmann E, et al. Prediction of treatment outcome in patients with chronic hepatitis $\mathrm{C}$ : significance of baseline parameters and viral dynamics during therapy. Hepatology 2003; 37:600-609.

9. Zeuzem S, Herrmann E, Lee JH, et al. Viral kinetics in patients with chronic hepatitis $\mathrm{C}$ treated with standard or peginterferon alpha2a. Gastroenterology 2001;120:1438-1447.

10. Sodek J, Ganss B, McKee MD. Osteopontin. Crit Rev Oral Biol Med 2000;11:279-303.

11. Chabas D. Osteopontin, a multi-faceted molecule. Med Sci (Paris) 2005;21:832-838.

12. Renkl AC, Wussler J, Ahrens T, et al. Osteopontin functionally activates dendritic cells and induces their differentiation toward a Th1-polarizing phenotype. Blood 2005;106:946-955.

13. Ashkar S, Weber GF, Panoutsakopoulou V, et al. Eta-1 (osteopontin): an early component of type-1 (cell-mediated) immunity. Science 2000;287:860-864.

14. Young MF, Kerr JM, Termine JD, et al. cDNA cloning, mRNA distribution and heterogeneity, chromosomal location, and RFLP analysis of human osteopontin (OPN). Genomics 1990;7:491-502.

15. Giacopelli F, Marciano R, Pistorio A, et al. Polymorphisms in the osteopontin promoter affect its transcriptional activity. Physiol Genomics 2004;20:87-96.

16. Hummelshoj T, Ryder LP, Madsen HO, Odum N, Svejgaard A. A functional polymorphism in the Eta-1 promoter is associated with allele specific binding to the transcription factor Sp1 and elevated gene expression. Mol Immunol 2006;43:980-986. 
17. Thursz M, Yee L, Khakoo S. Understanding the host genetics of chronic hepatitis B and C. Semin Liver Dis 2011;31:115-127.

18. Mochida S, Hashimoto M, Matsui A, et al. Genetic polymorphims in promoter region of osteopontin gene may be a marker reflecting hepatitis activity in chronic hepatitis $\mathrm{C}$ patients. Biochem Biophys Res Commun 2004;313:1079-1085.

19. Naito M, Matsui A, Inao M, et al. SNPs in the promoter region of the osteopontin gene as a marker predicting the efficacy of interferonbased therapies in patients with chronic hepatitis C. J Gastroenterol 2005;40:381-388.

20. Khuroo MS, Khuroo MS, Dahab ST. Meta-analysis: a randomized trial of peginterferon plus ribavirin for the initial treatment of chronic hepatitis C genotype 4. Aliment Pharmacol Ther 2004;20: 931-938.

21. Jacobson IM, Brown RS Jr, Freilich B, et al. Peginterferon alfa$2 \mathrm{~b}$ and weight-based or flat-dose ribavirin in chronic hepatitis $\mathrm{C}$ patients: a randomized trial. Hepatology 2007;46:971-981.

22. Colin C, Lanoir D, Touzet S, et al. Sensitivity and specificity of third-generation hepatitis $\mathrm{C}$ virus antibody detection assays: an analysis of the literature. J Viral Hepat 2001;8:87-95.

23. Simmonds P, Bukh J, Combet C, et al. Consensus proposals for a unified system of nomenclature of hepatitis $C$ virus genotypes. Hepatology 2005;42:962-973.

24. Ghany MG, Strader DB, Thomas DL, Seeff LB; American Association for the Study of Liver Diseases. Diagnosis, management, and treatment of hepatitis C: an update. Hepatology 2009;49:13351374.

25. Livak KJ. Allelic discrimination using fluorogenic probes and the 5 nuclease assay. Genet Anal 1999;14:143-149.

26. Norušis MJ. SPSS statistics 17.0: advanced statistical procedures companion. Upper Saddle River: Prentice Hall, 2009.

27. Devlin B, Risch N. A comparison of linkage disequilibrium measures for fine-scale mapping. Genomics 1995;29:311-322.

28. Peakall R, Smouse PE. GenAlEx 6: genetic analysis in Excel. Population genetic software for teaching and research. Mol Ecol Notes 2006;6:288-295.

29. Peakall R, Smouse PE. GenAlEx 6.5: genetic analysis in Excel. Population genetic software for teaching and research: an update. Bioinformatics 2012;28:2537-2539.

30. Szabo G, Dolganiuc A. Hepatitis C and innate immunity: recent advances. Clin Liver Dis 2008;12:675-692.

31. Cerny A, Chisari FV. Pathogenesis of chronic hepatitis C: immunological features of hepatic injury and viral persistence. Hepatology 1999;30:595-601.

32. Neumann AU, Lam NP, Dahari $\mathrm{H}$, et al. Hepatitis $\mathrm{C}$ viral dynamics in vivo and the antiviral efficacy of interferon-alpha therapy. Science 1998;282:103-107.

33. Yamamoto S, Hijiya N, Setoguchi M, et al. Structure of the osteopontin gene and its promoter. Ann N Y Acad Sci 1995;760:44-58. 